\title{
PENERAPAN MODEL PICTURE AND PICTURE UNTUK MENINGKATKAN HASIL BELAJAR IPS DI KELAS V SD KATOLIK KAKASKASEN
}

\author{
Marlin Katulung', Beatus Mendelson Laka ${ }^{2}$, Greiswati Tahulending ${ }^{3}$ \\ Pendidikan Guru Sekolah Dasar, Sekolah Tinggi Keguruan dan Ilmu Pendidikan Biak \\ Marlinkatulung7@gmail.com
}

\section{INFO ARTIKEL}

\section{Riwayat Artikel:}

Diterima: 01-Februari-2021

Disetujui: 30-Maret-2021

\section{Kata Kunci: \\ Model Penerapan Picture And} Picture Hasil Belajar IPS

\begin{abstract}
ABSTRAK
Abstrak: Penelitian ini dilakukan di SD Katolik Kakaskasen dalam pembelajaran IPS di kelas V SD, berdasarkan observasi yang dilakukan bahwa pada pembelajaran guru menggunakan metode ceramah sehingga mengakibatkan kurangnya pemahaman siswa pada materi yang diberikan. Karena dalam pembelajaran IPS tentang kegiatan ekonomi, siswa hanya mencatat materi yang disampaikan oleh guru dari buku cetak mengakibatkan hasil belajar siswa rendah. Dari 22 siswa yang ada di kelas V SD Katolik Kakaskasen 10 orang yang mendapat nilai di atas rata-rata yakni di atas 75, sedangkan 12 orang mendapat nilai di bawah 75. Dari masalah tersebut, maka perlu di adakan perbaikan dalam proses pembelajaran di kelas. Langkah-langkah yang bisa di lakukan untuk meningkatkan hasil belajar siswa yaitu dengan menerapkan model pembelajaran picture and picture, karena dalam pembelajaran ini semua siswa menjadi lebih aktif. Model picture and picture adalah salah satu model belajar yang menggunakan gambar dan di pasangkan di urutkan menjadi urutan yang logis. Tujuan dari penelitian ini adalah untuk meningkatkan hasil belajar IPS pada materi kegiatan ekonomi melalui penerapan model picture and picture di kelas V SD Katolik Kakaskasen. Penelitian ini dilaksanakan dalam bentuk penelitian tindakan kelas (PTK) yang terdiri empat tahapan yaitu : (1) Perencanaan, (2) Pelaksanaan/Tindakan, (3) Observasi, (4) refleksi. Penelitian ini di lakukan dalam 2 (Dua) Siklus. Pada siklus yang ke II hasil yang dicapai setelah mengadakan perbaikan tindakan pembelajaran yang diterapkan ternyata mengalami peningkatan yang cukup baik dan dibuktikan berdasarkan teknik pengumpulan data yaitu lembar pengamatan dan tes tertulis sehingga mencapai target yang diharapkan karena keberhasilan siswa mencapai $85 \%$ berdasarkan data tersebut maka peneliti dapat menarik kesimpulan bahwa Dari hasil penelitian dan pembahasan yang ada, maka peneliti menarik kesimpulan bahwa Penerapan model picture and picture dapat meningkatkan hasil belajar IPS siswa kelas V SD Katolik Kakaskasen.
\end{abstract}

Abstrack: This research was conducted at Kakaskasen Catholic Elementary School in social studies learning in grade $V$,, based on observations made that upon learning teacher uses the lecture method resulting in a lack of student understanding of the material provided. Because social studies learning about economic activities, students only record material presented by the teacher from printed books resulting in low student learning outcomes. Of the 22 students in the fifth grade of the Kakaskasen Catholic Elementary School, 10 of them scored above the average, which is above 75, while 12 students scored below 75. From these problems, it is necessary to make improvements in the learning process in the classroom. The steps that can be taken to improve student learning outcomes are by applying the picture and picture learning model, because in this type of learning all students become more active. The picture and picture model is a learning model that uses pictures and pairs them in a logical order. The purpose of this study was to improve social studies learning outcomes in the material of economic activity through the application of the picture and picture model in grade $V$ at Kakaskasen Catholic Elementary School. This research was conducted in the form of classroom action research (PTK) which consisted of four stages, namely: (1) planning, (2) implementation / action, (3) observation, (4) reflection. This research was conducted in 2 (two) cycles. In the second cycle, the results achieved after making improvements to the learning actions that were applied turned out to have increased quite well and were proven based on data collection techniques, namely observation sheets and written tests so that they achieved the expected targets because the success of students reached $85 \%$ based on these data, the researchers could draw the conclusion that from the results of the existing research and discussion, the researcher draws the conclusion that the application of the picture and picture model can improve social studies learning outcomes for fifth grade students of Catholic Elementary School Kakaskasen. 


\section{A. LATAR BELAKANG}

Ilmu Pengetahuan Sosial (IPS) adalah salah satu mata pelajaran di SD yang terdiri atas dua bahan kajian pokok : Pengetahuan sosial dan sejarah. Pengetahuan sosial mencakup antropologi, sosiologi, geografi, ekonomi, dan tata Negara. Bahan kajian sejarah meliputi perkembangan masyarakat Indonesia sejak masa lalu hingga masa kini (KTSP. 2008. Pendidikan IPS di SD). Perlu disadari bahwa, sesuai dengan tingkat perkembangannya siswa sekolah dasar belum mampu memahami keluasan dan kedalaman masalah-masalah tersebut. Melalui pengajaran IPS siswa dapat memperoleh pengetahuan, ketrampilan sikap, dan kepekaan, untuk menghadapi hidup dengan tantangan-tantangannya. Selanjutnya kelak mereka diharapkan mampu bertindak secara rasional dalam memecahkan masalah-masalah yang dihadapi.

Menurut Soemantri Tim Pustaka Yustisia, (2008) "Ilmu pengetahuan Sosial merupakan gabungan dari unsur-unsur geografi, sejarah, ekonomi, hukum dan politik, kewarganegaraan, sosiologi bahkan bidang-bidang humaniora, pendidikan dan agama". Dari uraian di atas dapat disimpulkan bahwa Ilmu Pengetahuan Sosial adalah mata pelajaran yang membekali siswa dengan pengetahuan, sikap dan ketrampilan yang berguna dalam pengembangan pribadi dan kehidupannya sehari-hari.

Menurut Aqib (2013) Metode Pembelajaran Picture and picture seperti halnya metode example nonexample didasarkan atas contoh. Sejalan dengan pendapat diatas menurut Suprijono dalam Huda (2014) menyatakan bahwa picture and picture merupakan model pembelajaran yang menggunakan gambar sebagai media pemelajaran. Strategi ini mirip dengan example non example dimana gambar yang di berikan pada siswaharus diurutkan scara logis. Menurut Johnson and Jhonson (2009), prinsip dasar dalam model pembelajaran kooperatif picture and picture adalah sebagai berikut : (1) setiap anggota kelompok (siswa) bertanggung jawab atas segala sesuatu yang di kerjakan dalam kelompoknya, (2) setiap anggota kelompok (siswa) harus mengetahui bahwa semua anggota kelompok mempunyai tujuan yang sama, (3) setiap anggota kelompok (siswa) harus membagi tugas dan tanggung jawab yang sama di antara anggota kelompoknya, (4) setiap anggota kelompok (siswa) akan di kenai evaluasi, (5) setiap anggota kelompok (siswa) berbagi kepemimpinan dan membutuhkan ketrampilan untuk belajar bersama selama proses belajarnya, (6) setiap kelompok (siswa) akan di minta mempertanggung jawabkan secara individual materi yang di tangani dalam kelompok kooperatif. Model pembelajaran merupakan salah satu komponen penting dalam pembelajaran. Ada beberapa alasan pentingnya pengembangan model pembelajaran, yaitu: a) model pembelajaran yang efektif sangat membantu dalam proses pembelajaran sehingga tujuan pembelajaran lebih mudah tercapai, b) model pembelajaran dapat memberikan informasi yang berguna bagi peserta didik dalam proses pembelajarannya, c) variasi model pembelajaran dapat memberikan gairah belajar peserta didik, menghindari rasa bosan, dan akan berimplikasi pada minat serta motivasi peserta didik dalam mengikuti proses pembelajaran, d) mengembangkan ragam model pembelajaran sangat urgen karena adanya perbedaan karakteristik, kepribadian, kebiasaan-kebiasaan cara belajar para peserta didik, e) kemampuan dosen/guru dalam menggunakan model pembelajaran pun beragam, dan mereka tidak terpaku hanya pada model tertentu, dan f) tuntutan bagi dosen/guru profesional memiliki motivasi dan semangat pembaharuan dalam menjalankan tugas/profesinya (Asyafah Abas, 2019).

Untuk itu dalam mencapai tujuan pembelajaran perlu di terapkan model pembelajaran picture and picture dalam kegiatan belajar mengajar, khususnya dalam pembelajaran IPS. Dari berbagai definisi diatas, dapat disimpulkan bahwa model pembelajaran picture and picture adalah mengandalkan gambar sebagai media dalam proses pembelajaran karena gambar-gambar tersebut adalah faktor utama dalam proses pembelajaran untuk mencapai tujuan pembelajaran.

Langkah-langkah Model pembelajaran Picture and Picture: 1) Guru menyampaikan kompetensi yang ingin di capai; 2) Menyajikan materi sebagai pengantar; 3) Guru menunjukkan/memperlihatkan gambar-gambar kegiatan yang berkaitan dengan materi; 4) Guru menunjukkan/memanggil siswa secara bergantian memasang/mengurutkan gambar-gambar menjadi urutan yang logis; 5) Guru menanyakan alasan/dasar pemikiran urutan gambar tersebut; 6) Dari alasan/urutan tersebut guru memulai menanamkan konsep/materi sesuai dengan kompetensi yang ingin dicapai; 7) Kesimpulan rangkuman.

Kelebihan model pembelajaran Picture and Picture yaitu: 1) Guru lebih mengetahui kemampuan masingmasing siswa; 2) Melatih berfikir logis dan sistematis; 3) Membantu siswa belajar berpikir berdasarkan sudut pandang suatu objek bahasan dengan memberikan kebebasan siswa dalam praktik perpikir: 4) Mengembangkan motivasi untuk belajar yang lebih baik; 5) Siswa dilibatkan dalam perencanaan dan pengelolaan kelas. Selanjutnya kekurangan model pembelajaran Picture and Picture yaitu: 1) Memakan banyak waktu; 2) Banyak siswa yang pasif; 3) Guru khawatir bahwa akan terjadi kekacauan di kelas; 4) Banyak siswa tidak senang apabila di suruh bekerja sama dengan yang lain; 5) Di butuhkan dukungan fasilitas, alat dan biaya yang cukup memadai.

Penggunaan Model pembelajaran Picture and Picture dalam pembelajaran IPS di SD dapat membantu siswa untuk berfikir logis terhadap kejadian sehari-hari dan memecahkan masalah-masalah sederhana yang di 
hadapinya, untuk itu, pembelajaran IPS dapat menyenangkan siswa yang diam-diam tertarik pada suatu masalah, baik itu masalah kegiatan sehari-hari maupun masalah lingkungan sekitar dalam kegiatan ekonomi. Karena itu, pembelajaran IPS sangat berhubungan dengan model picture and picture sebab dalam proses pembelajaran IPS, model yang paling tepat di gunakan yaitu model picture and picture. Karena sebagian besar pokok bahasan yang ada dalam mata pelajaran IPS, harus menggunakan model picture and picture.

Di dalam proses belajar mengajar, guru harus memiliki strategi agar siswa dapat belajar secara aktif dan efisien sesuai dengan tujuan yang diharapkan. Salah satu langkah untuk memiliki strategi itu ialah harus menguasai teknik-teknik penyajian atau metode mengajar. Cara guru mengajar di kelas menggunakan model picture and picture adalah merupakan suatu cara mengajar di mana siswa diberikan kesempatan untuk memahami sendiri, mengikuti proses belajar mengajar dalam mengurutkan gambar-gambar sesuai dengan urutan yang logis.

Ilmu Pengetahuan Sosial (IPS) yang berasal dari kata social studies, social studies artinya ilmu-ilmu sosial yang di sederhanakan untuk tujuan pendidikan, social studies meliputi aspek-aspek ilmu sejarah, ilmu ekonomi, ilmu politik, sosiologi, antropologi, psikologi, ilmu geografi, dan filsafat yang dalam praktiknya di pilih untuk tujuan pembelajaran di sekolah dasar (SD), sejak awal pertumbuhannya bidang "social studies" dihadapkan kepada tantangan untuk dapat membangun dirinya sebagai suatu disiplin yang solid. Sardiyo dkk (2007:25), mengemukakan bahwa ilmu pengetahuan sosial adalah bidang studi yang mempelajari dan menelaah dari berbagai aspek kehidupan secara terpadu. Rudy Gunawan (2011), Ilmu pengetahuan sosial adalah suatu bahan kajian yang terpadu yang merupakan penyerdehanaan, adaptasi, seleksi, dan modifikasi yang diorganisasikan dari konsep-konsep dan ketrampilan sejarah, sosiologi, antropologi, dan ekonomi. Jadi konkretnya tujuan ilmu pengetahuan sosial adalah membina anak didik menjadi warga Negara yang baik, yang memiliki pengetahuan ketrampilan sosial yang berguna bagi dirinya sendiri serta masyarakat dan Negara, untuk merealisasikan tujuan tersebut, proses belajar dalam membelajarkannya tidak hanya terbatas pada aspek kognitif dan psikomotor saja, melainkan meliputi aspek afektif. Dari berbagai definisi diatas, dapat disimpulkan bahwa pengertian IPS adalah suatu program pendidikan yang merupakan suatu keseluruhan yang pada intinya mempelajari tentang manusia dan lingkungan alam fisik maupun lingkungan sosial.

Pelajaran IPS di SD harus memperhatikan kebutuhan anak yang berusia 6-12 tahun. Anak dalam kelompok 7-11 tahun menurut Piaget (Rudy Gunawan, 2011) berada dalam perkembangan kemampuan intelektual/kognitifnya pada tingkatan kongkret operasional. Mereka memandang dunia dalam keseluruhan yang utuh, dan menganggap tahun yang akan datang sebagai waktu yang masih jauh. Yang mereka pedulikan adalah sekarang (kongkrit), dan bukan masa depan yang belum mereka pahami (abstrak). Padahal bahan materi IPS penuh dengan pesan-pesan yang bersifat abstrak. Konsep-konsep waktu, perubahan, kesinambungan menurut (continuity), arah mata angin, lingkungan, ritual, akulturasi, kekuasaan, demokrasi, nilai, peranan, permintaan, atau kelangkaan adalah konsep-konsep abstrak yang dalam program studi IPS harus dibelajarkan kepada siswa SD.

Pembalajaran IPS di SD bertujuan agar siswa mampu mengembangkan pengetahuan dan ketrampilan dasar yang berguna bagi dirinya dalam kehidupan sehari-hari. Pelajaran sejarah bertujuan agar siswa mampu mengembangkan pemahaman tentang perkembangan masyarakat Indonesia sejak masa lalu hingga masa kini, sehingga memiliki kebangaan sebagai bangsa Indonesia dan cinta tanah air. Menurut Rudy Gunawan (2011), Mata pelajaran IPS bertujuan agar anak didik memiliki kemampuan sebagai berikut: 1) Mengenal konsepkonsep yang berkaitan dengan kehidupan masyarakat; 2) Memiliki kemampuan dasar untuk berfikir logis dan kritis, rasa ingin tahu, inkuiri, memecahkan masalah dan ketrampilan dalam kehidupan sosial; 3) Memiliki komitmen dan kesadaran terhadap nilai-nilai sosial dan kemanusiaan; 4) Memiliki kemampuan berkomunikasi, bekerja sama, dan berkompetisi dalam masyarakat yang majemuk, ditingkat lokal, nasional, dan global.

Menurut Oemar Hamalik (1994), belajar adalah modifikasi atau memperteguh kekuatan melalui pengalaman. Menurut pengertian, belajar adalah merupakan suatu proses suatu kegiatan dan bukan suatu hasil atau tujuan. Belajar bukan hanya mengingat, akan tetapi lebih luas dari pada itu, yaitu mengalami hasil belajar bukan suatu penguasaan hasil latihan, melainkan perubahan kelakuan. Belajar adalah perubahan yang terjadi dalam kemampuan manusia yang terjadi setelah belajar secara terus menerus, bukan hanya disebabkan oleh proses pertumbuhan saja, menurut Gagne syaiful sagala, (2009). Siswa adalah subjek yang terlibat dalam kegiatan belajar mengajar disekolah.

Di Indonesia, hasil belajar dinyatakan dalam klasifikasi yang dikembangkan oleh bloom dan kawan kawannya. Bloom membagi hasil belajar atas tiga ranah yaitu : kognitif, afektif dan psikomotor. Ranah kognitif berhubungan dengan kemampuan berpikir, ranah afektif berhubungan dengan perasaan, dan ranah psikomotor berhubungan dengan persoalan ketrampilan motorik yang di kendalikan oleh kematangan psikologis. Secara singkat dapat di simpulkan bahwa, hasil belajar adalah kemampuan (kognitif, afektif dan psikomotor) yang di dapat setelah mempelajari sesuatu. Jadi dapat dikatakan bahwa hasil belajar hanya akan di dapat setelah terjadi 
proses belajar. Untuk menyatakan bahwa suatu proses belajar mengajar dapat dikatakan berhasil, setiap guru mempunyai pandangan masing-masing sejalan dengan filsafatnya. Namun untuk menyamakan apersepsi sebaiknya berpedoman pada kurikulum yang berlaku saat ini. Antara lain, bahwa suatu proses belajar mengajar tentang sesuatu bahan pengajaran dinyatakan berhasil apabila kompetensi dasarnya tercapai.

Hasil belajar IPS tentu saja harus di kaitkan dengan tujuan pembelajaran IPS yang telah dicantumkan dalam garis-garis besar program pengajaran IPS di sekolah dengan tidak melupakan hakikat IPS itu sendiri. Jadi, hasil belajar IPS di kelompokkan berdasarkan hakikat IPS itu sendiri, yaitu sebagai produk dan proses. Dari berbagai definisi diatas dapat disimpulkan bahwa hasil belajar adalah perubahan tingkah laku seorang siswa, dari yang sebelumnya tidak tahu menjadi tahu. Tetapi tidak hanya mencakup kognitif saja melainkan afektif dan juga psikomotor.

Berdasarkan pada penelitian yang dilakukan di SD Katolik Kakaskasen dalam pembelajaran IPS di kelas V $\mathrm{SD}$, guru menggunakan metode ceramah sehingga siswa kurang memahami materi yang diberikan karena dalam pembelajaran tentang kegiatan ekonomi, siswa hanya mencatat materi yang disampaikan oleh guru dari buku cetak mengakibatkan hasil belajar rendah. Dari 22 siswa yang ada di kelas V SD Katolik Kakaskasen 10 orang yang mendapat nilai di atas rata-rata yakni di atas 75 , sedangkan 12 orang mendapat nilai di bawah 75 .

Dari masalah tersebut, maka perlu di adakan perbaikan dalam proses pembelajaran di kelas. Peningkatan aktivitas siswa dalam proses pembelajaran, akan membuat pelajaran lebih bermakna dan berarti dalam kehidupan siswa, sehingga hasil belajar dapat tercapai. Langkah-langkah yang bisa di lakukan untuk meningkatkan hasil belajar siswa yaitu dengan menerapkan model picture and picture, karena dalam pembelajaran ini semua siswa menjadi lebih aktif. Model picture and picture adalah salah satu model belajar yang menggunakan gambar dan di pasangkan di urutkan menjadi urutan yang logis. Berdasarkan latar belakang tersebut, peneliti memilih judul penelitian ini adalah "Penerapan Model Picture And Picture untuk Meningkatkan Hasil belajar IPS di kelas V SD Katolik Kakaskasen. Adapun yang menjadi tujuan penelitian ini adalah untuk meningkatkan hasil belajar IPS pada materi kegiatan ekonomi melalui penerapan model picture and picture di kelas V SD Katolik Kakaskasen.

\section{B. METODE PENELITIAN}

Jenis penelitian ini adalah penelitian tindakan kelas. Peneliti menggunakan PTK menurut Kemmis dan Mc Taggart dalam Aqib Zainal, (2006) yang terdiri empat tahapan yaitu: (1) Perencanaan, (2) Pelaksanaan/Tindakan, (3) Observasi, (4) refleksi. Penelitian ini di lakukan dalam 2 (Dua) Siklus. Masingmasing tahapan ini akan di jelaskan pada alur peneliatian melalui gambar berikut:

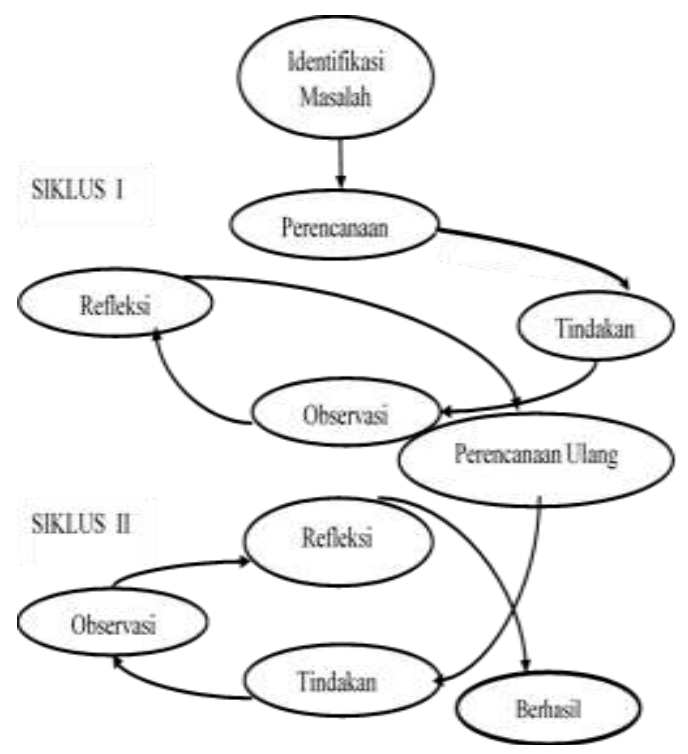

Gambar 1. Siklus penelitian menurut Kemmis \& Mc Taggart dalam Aqib Zainal (2006)

Adapun penelitian yang dilakukan peneliti dengan menggunakan dua siklus. Pada masing-masing siklus dengan tahapan mulai dari perencanaan, pelaksanaan, observasi dan tahap refleksi. Lokasi penelitian ini adalah SD Katolik Kakaskasen. Sampel yang peneliti ambil yaitu siswa kelas V dengan jumlah siswa sebanyak 22 siswa. Teknik pengumpulan data yang digunakan yaitu berupa observasi, tes yang terdiri dari tes lisan dan tes tertulis. Teknik analisis data yang digunakan adalah analisis berdasarkan ketentuan belajar siswa dan memperhitungkan presentasi keberhasilan belajar siswa dengan cara membandingkan hasil capaian belajar pada 
setiap siklus penelitian dengan pencapaian yang di capai yaitu 90\%. Untuk meningkatkan hasil belajar siswa dapat di hitung dengan menggunakan rumus sebagai berikut:

$$
\mathrm{KB}=\frac{T}{T t} \times 100 \% \quad \text { Trianto (2011) }
$$

Dimana: $\mathrm{KB} \quad=$ Ketuntasan belajar

$\mathrm{T} \quad=$ Jumlah skor yang di peroleh siswa

$\mathrm{Tt}=$ Jumlah skor total

\section{HASIL DAN PEMBAHASAN}

Penelitian dilaksnanakan di SD Katolik Kakaskasen pada pembelajaran IPS di kelas V semester II (Genap). Penelitian ini dilaksanakan dengan menggunakan model picture and picture pada pembelajaran IPS tentang jenis-jenis kegiatan Ekonomi untuk meningkatkan hasil belajar siswa. Waktu pelaksanaan penelitian ini dilakukan dalam 2 (dua) siklus, dimana masing-masing siklus terdiri satu kali pertemuan dengan waktu 2 x 35 menit. Penelitian ini juga melibatkan guru kelas sebagai observer (pengamat), karena penelitian ini bersifat kolaborasi.

Berikut ini deksripsi tindakan pembelajaran IPS dengan model picture and picture pada siswa kelas V SD Katolik Kakaskasen yang dilaksanakan dalam dua siklus yang diuraikan sebagai berikut :

1. Deskripsi data siklus I

a) Perencanaan: Pada siklus ini pembelajaran direncanakan I (satu) ksli pertemuan dengan waktu 2 x 35 menit, dan dengan kompetensi dasar mengindentifikasi jenis-jenis kegiatan ekonomi melalui pengamatan dengan indikator capaiannya: (1) mengindentifikasi jenis kegiatan ekonomi. (2) menyebutkan jenis-jenis kegiatan ekonomi. Dalam perencanaan tindakan ini mempersiapkan materi yang akan diajarkan, disesuaikan dengan langkah-langkah pembelajaran. Hal-hal yang di persiapkan adalah: 1) Rencana pelaksanaan pembelajaran (RPP); 2) Media pembelajaran dalam hal ini berupa alat peraga sederhana yang digunakan dalam proses pembelajaran yaitu karton yang sudah ditempeli dengan gambar-gambar tentang kegiatan ekonomi; 3) Lembar kerja siswa (LKS); 4) Menyiapkan lembar penilaian (Evaluasi); 5) Menyiapkan lembar instrument untuk pengamatan interaksi kegiatan belajar mengajar

b) Pelaksanaan Tindakan: Pelaksanaan tindakan merupakan implementasi dari semua rencana yang telah dibuat atau sesuai dengan urutan proses pembelajaran yang telah disusun peneliti pada tahap perencanaan. Maka pelaksanaan tindakannya dapat dilihat sebagai berikut:

1) Kegiatan awal: Kegiatan awal yang dilakukan dalam kegiatan mengajar sebagai berikut: Menyampaikan salam pembuka; Berdoa dengan memanggil salah satu siswa untuk mempimpin; Memeriksa kesiapan siswa untuk menerima pelajaran; Mengabsensi siswa; Melakukan apersepsi

2) Kegiatan Inti: Langkah I guru menyampaikan kompetensi yang ingin dicapai

Kegiatan ini dilakukan untuk menyampaikan apakah yang menjadi kompetensi dasar mata pelajaran yang akan diajarkan, dengan demikian maka siswa dapat mengukur sampai sejauh mana yang harus dikuasainya mata pelajaran yang akan diajarkan, di samping itu guru juga harus menyampaikan indikatorindikator ketercapaian kompetensi dasar, sehingga sampai sejauh mana KKM yang telah ditetapkan dapat dicapai oleh peserta didik. Langkah II, menyajikan materi sebagai pengantar dimana guru (peneliti) memberikan momentum permulaan pembelajaran, kesuksesan dalam pembelajaran dapat dimulai dari penyajian materi, karena guru dapat memberikan motivasi yang menarik perhatian siswa yang belum siap. Dengan motivasi dan teknik yang baik dalam pemberian materi akan menarik minat siswa untuk belajar lebih jauh materi yang dipelajari. Dengan cara guru membagi kelompok siswa bisa bekerja sama dan saling membantu.

Langkah III, Guru menunjukan/memperlihatkan gambar-gambar kegiatan berkaitan dengan materi. Dalam proses penyajian materi, guru mengajar setiap kelompok ikut terlibat aktif dalam proses pembelajaran dengan mengamati setiap gambar yang ditunjukan oleh guru atau oleh temannya. Dengan picture atau gambar kita akan menghemat energi kita dan siswa akan lebih mudah memahami yang akan diajarkan.

Langkah IV, Guru menunjuk/memanggil siswa secara bergantian memasang/mengurutkan gambargambar menjadi urutan yang logis. Guru menunjuk siswa untuk maju secara bergantian untuk memasang gambar. Gambar-gambar yang sudah ada diminta oleh siswa untuk diurutkan, dibuat atau dimodifikasi.

Langkah V, Guru menanyakan alasan/dasar pemikiran urutan gambar tersebut. Disini guru mengajak siswa menemukan rumus, tinggi, jalan cerita, atau tuntutan kompetensi dasar dengan indikator yang akan dicapai. Ajaklah sebanyak-banyaknya peran siswa dan teman yang lain untuk membantu sehingga proses diskusi dalam PBM semakin menarik. 
Langkah VI, dari alasan/urutan gambar tersebut guru memulai menanamkan konsep/materi sesuai dengan kompetensi yang ingin dicapai. Dalam proses diskusi dan pembacaan sumber guru. Harus memberikan penekanan-penekanan pada hal ini dicapai dengan meminta siswa lain untuk mengulangi, menuliskan atau bentuk lain dengan tujuan siswa mengetahui bahwa hal tersebut penting dalam pencapaian kompetensi dasar dan indikator yang telah ditetapkan.

c) Kegiatan Akhir: Pada tahap ini, guru bersama-sama siswa membuat kesimpulan materi yang telah dipelajari. Salah satu siswa memimpin doa untuk mengakhiri pembelajaran.

d) Observasi: Kegiatan ini dilaksanakan dalam rangka untuk mengetahui kelangsungan pembelajaran. Saat kegiatan pembelajaran dimulai, kegiatan observasi pada siklus I ini dilaksanakan bersama-sama guru kelas dan peneliti sendiri. Pelaksanaan observasi ini berlangsung bersamaan dengan proses pembelajaran yang meliputi aktivitas guru dan siswa, pengembangan materi, dan hasil belajar siswa. Aktivitas guru dan siswa, bisa dilihat dari instrument interaksi belajar mengajar yang disediakan oleh peneliti, dimana dapat diketahui peningkatan aktivitas siswa dalam belajar IPS. Pengembangan materi dapat dilihat dari lembar pedoman observasi dari peneliti yang disediakan di mana dapat diketahui cara mengajar dan penyajian materi yang dilakukan peneliti, apa sudah maksimal atau belum. Sedangkan hasil belajar siswa dapat dilihat dari lembar evaluasi yang dikerjakan oleh siswa untuk menunjukan sejauh mana pengingkatan prestasi belajar siswa, serta keberhasilan dan pencapaian tujuan penelitian. Secara umum siswa senang dalam pembelajaran yang dilakukan walaupun masih ada beberapa siswa kurang bahkan tidak aktif disaat pembelajaran, ditiap kelompok ada anggotanya hanya bermain dan tidak bekerjasama untuk melakukan picture and picture. Media yang dipakai masih kurang, serta pertanyaan hanya dilontarkan pada tiap kelompok. Setelah diberikan evaluasi siswa terlalu banyak bermain, sehingga akhir evaluasi yang mereka dapat tidak sesuai dengan yang diharapkan.

e) Refleksi: Setelah direfleksi tindakan siklus I ternyata masih banyak kendala-kendala yang ditemukan dalam proses pembelajaran, terlebih hasil evaluasi yang belum memenuhi syarat tuntas belajar atau belum memenuhi target yang diharapkan sehingga perlu lagi tuntunan motivasi dari guru. Dibawah ini dapat dilihat hasil pada siklus I.

\section{Hasil Siklus I}

Hasil pembelajaran siswa kelas V SD Katolik Kakaskasen dengan penerapan model Picture and picture, materi kegiatan Ekonomi dilihat pada tabel di bawah ini.

\begin{tabular}{|c|c|c|c|c|c|c|c|c|c|}
\hline \multirow{2}{*}{ No } & \multirow{3}{*}{ Nama Siswa } & \multirow{2}{*}{\multicolumn{5}{|c|}{ Skor setiap soal }} & \multirow{3}{*}{$\begin{array}{c}\begin{array}{c}\text { Jumlah } \\
\text { skor }\end{array} \\
50\end{array}$} & \multicolumn{2}{|c|}{ Ketuntasan belajar } \\
\hline & & & & & & & & ya & Tidak \\
\hline 1 & & 10 & 10 & 10 & 20 & - & & & $\sqrt{ }$ \\
\hline 2 & $\mathrm{HL}$ & 10 & 10 & 20 & - & - & 40 & & $\sqrt{ }$ \\
\hline 3 & KM & - & - & 10 & 20 & 10 & 40 & & $\sqrt{ }$ \\
\hline 4 & NS & 10 & 10 & - & 20 & - & 40 & & $\sqrt{ }$ \\
\hline 5 & $\mathrm{CR}$ & 10 & 20 & 10 & 20 & 20 & 80 & $\sqrt{ }$ & \\
\hline 6 & WH & 10 & - & 10 & 20 & 10 & 50 & & $\sqrt{ }$ \\
\hline 7 & VL & 10 & 20 & 10 & 20 & 20 & 80 & $\sqrt{ }$ & \\
\hline 8 & JA & 10 & 10 & 10 & 10 & - & 40 & & $\sqrt{ }$ \\
\hline 9 & JT & 5 & 20 & 10 & 25 & 20 & 80 & $\sqrt{ }$ & \\
\hline 10 & $\mathrm{AL}$ & 10 & 20 & 10 & - & 10 & 50 & & $\sqrt{ }$ \\
\hline 11 & GD & 10 & 20 & 10 & 20 & 20 & 80 & $\sqrt{ }$ & \\
\hline 12 & JK & 10 & - & 10 & 10 & 10 & 40 & & $\sqrt{ }$ \\
\hline 13 & AM & 10 & - & 10 & - & - & 20 & & $\sqrt{ }$ \\
\hline 14 & DT & 10 & 20 & 20 & 25 & 25 & 100 & $\sqrt{ }$ & \\
\hline 15 & BW & - & 20 & 10 & 25 & 25 & 80 & $\sqrt{ }$ & \\
\hline 16 & JP & 10 & 20 & 10 & - & - & 40 & & $\sqrt{ }$ \\
\hline 17 & AR & 10 & 10 & 20 & 20 & 20 & 80 & $\sqrt{ }$ & \\
\hline 18 & VM & 10 & 20 & 20 & - & - & 50 & & $\sqrt{ }$ \\
\hline 19 & MS & 10 & 10 & 20 & 20 & 20 & 80 & $\sqrt{ }$ & \\
\hline 20 & JM & 10 & 10 & 20 & 20 & 20 & 80 & $\sqrt{ }$ & \\
\hline 21 & ES & 10 & 20 & 20 & 25 & 25 & 100 & $\sqrt{ }$ & \\
\hline 22 & $\mathrm{CS}$ & 10 & - & 10 & 20 & 10 & 50 & & $\sqrt{ }$ \\
\hline \multicolumn{2}{|c|}{ Jumlah keseluruhan } & 195 & 270 & 280 & 340 & 265 & 1350 & & \\
\hline
\end{tabular}

$$
\mathrm{KB}=\frac{1.350}{2.200} \times 100 \%=61,36 \%
$$


Berdasarkan hasil refleksi yang dilakukan peneliti pada siklus I dapat di simpulkan bahwa pelaksanaan pembelajaran dengan menggunakan model picture and picture perlu diperbaiki pada siklus selanjutnya.

\section{Deskripsi Data Siklus II}

a) Perencanaan: Siklus II ini merupakan perbaikan dari siklus I dan materi yang akan di bahas pada siklus II sama seperti pada siklus I. Namun yang diubah adalah cara mengajar guru yang belum membuat siswa serius dalam mengikuti kegiatan pembelajaran, dan bagaimana guru dapat berhasil menerapkan model picture and picture dalam pembelajaran sehingga memotivasi siswa untuk menerima pelajaran, sehingga dapat meningkatkan hasil belajar siswa pada siklus II ini. Dalam penelitian siklus II ini hal yang peneliti untuk melaksanakan kegiatan pembelajaran yaitu: 1) Rencana pelaksanaan pembelajaran (RPP); 2) Media pembelajaran dalam hal ini berupa alat peraga sederhana yang digunakam dalam proses pembelajaran yaitu karton yang sudah ditempeli dengan gambar-gambar tentang kegiatan Ekonomi; 3) Lembar kerja siswa (LKS); 4) Menyiapkan lembar penelitian (Evaluasi); 5) Menyiapkan lembar instrument untuk pengamatan interaksi kegiatan belajar mengajar.

b) Pelaksanaan Tindakan: Siklus II ini dilakukan untuk memperbaiki kekurangan yang dilakukan pada siklus I. Hal yang dicapai dalam siklus I akan di perbaharui pada siklus II ini. Pelaksanaan tindakan pada siklus II ini dengan materi yang sama pada siklus I dengan menerapkan model picture and picture untuk meningkatkan hasil belajar siswa, dan dengan langkah-langkah pembelajaran sebagai berikut :

1) Kegiatan Awal: Pada tahap ini guru (peneliti) memberikan salam kepada seluruh siswa, kemudian guru mengatur posisi duduk siswa agar duduk dengan tenang pada tempat duduknya masing-masing, karena kegiatan pembelajaran akan dimulai. Kemudian guru mengecek kehadiran siswa, setelah selesai dilanjutkan dengan apersepsi dimana guru mengaitkan materi yang akan dibahas yaitu tentang jenisjenis kegiatan Ekonomi dengan pengalaman dalam kehidupan sehari-hari. Dan jawaban siswa dari pertanyaan guru menjadi dasar untuk melibatkan pengetahuan siswa.

2) Kegiatan Inti: Langkah I, guru menyampaikan kompetensi yang ingin dicapai. Kegiatan ini dilakukan untuk menyampaikan apakah yang menjadi kompetensi dasar mata pelajaran yang akan diajarkan, dengan demikian maka siswa dapat mengukur sampai sejauh mana yang harus dikuasainya mata pelajaran yang akan diajarkan, di samping itu guru juga harus menyampaikan indikator-indikator ketercapaian kompetensi dasar, sehingga sampai sejauh mana KKM yang telah ditetapkan dapat dicapai oleh peserta didik.

Langkah II, menyajikan materi sebagai pengantar. Guru (peneliti) memberikan momentum permulaan pembelajaran, kesuksesan dalam pembelajaran dapat dimulai dari penyajian materi, karena guru dapat memberikan motivasi yang menarik perhatian siswa yang belum siap. Dengan motivasi dan teknik yang baik dalam pemberian materi akan menarik minat siswa untuk belajar lebih jauh materi yang dipelajari. Guru bisa membagi beberapa kelompok belajar. Dengan adanya kelompok setiap kelompok bisa bekerja sama dan saling membantu.

Langkah III, Guru menunjukan/memperlihatkan gambar-gambar kegiatan berkaitan dengan materi. Dalam proses penyajian materi, guru mengajar siswa ikut terlibat aktif dalam proses pembelajaran dengan mengamati setiap gambar yang ditunjukan oleh guru atau oleh temannya agar siswa bisa mengerti apa yang ada di gambar tesebut. Dengan picture atau gambar kita akan menghemat energi kita dan siswa akan lebih mudah memahami yang akan diajarkan. Langkah IV, Guru menunjuk/memanggil siswa secara bergantian memasang/mengurutkan gambar-gambar menjadi urutan yang logis. Dilangkah ini guru harus dapat melakukan inovasi, karena menunjukan secara langsung kadang kurang efektif dan siswa merasa terhukum. Salah satu cara adalah dengan undian, sehingga siswa merasa memang harus menjalankan tugas yang harus diberikan. Gambar-gambar yang sudah ada diminta oleh siswa untuk diurutkan, dibuat atau dimodifikasi. Langkah V, Guru menanyakan alasan/dasar pemikiran urutan gambar tersebut. Disini guru mengajak siswa menemukan rumus, tinggi, jalan cerita, atau tuntutan kompetensi dasar dengan indikator yang akan dicapai. Ajaklah sebanyak-banyaknya peran siswa dan teman yang lain untuk membantu sehingga proses diskusi dalam PBM semakin menarik. Langkah VI, Dari alasan/urutan gambar tersebut guru memulai menanamkan konsep/materi sesuai dengan kompetensi yang ingin dicapai.

Dalam proses diskusi dan pembacaan sumber guru. Harus memberikan penekanan-penekanan pada hal ini dicapai dengan meminta siswa lain untuk mengulangi, menuliskan atau bentuk lain dengan tujuan siswa mengetahui bahwa hal tersebut penting dalam pencapaian kompetensi dasar dan indikator yang telah ditetapkan.

c) Kegiatan Akhir: Pada tahap ini, guru bersama-sama siswa membuat kesimpulan materi yang telah dipelajari. Salah satu siswa memimpin doa untuk mengakhiri pembelajaran 
d) Observasi: Berdasarkan pengamatan guru kelas dapat dikemukakan bahwa peneliti telah melaksanakan kegiatan pembelajaran dari awal sampai akhir dengan baik, dapat mengelola kelas dan menciptakan suasana belajar yang kondusif dan menjadikan siswa aktif dalam belajar, siswa mengalami peningkatan dalam proses menerima pelajaran, semua siswa dalam setiap kelompok aktif, memperhatikan dengan baik penjelasan guru, dan ada respon dari siswa sehingga proses belajar berjalan dengan aktif. Setelah datang pada evaluasi semua siswa tidak mengalami kesulitan dalam menjawab setiap soal yang diberikan. Dan hasil pun sesuai dengan yang diharapkan atau mencapai ketuntasan belajar.

e) Refleksi: Dari kegiatan pembelajaran yang sudah dilaksanakan pada siklus ke II ini, peneliti dapat merefleksi hasil yang diperoleh pada kegiatan pembelajaran telah mencapai tuntas belajar. Dibawah ini dapat dilihat hasil belajar pada siklus II.

\begin{tabular}{|c|c|c|c|c|c|c|c|c|c|}
\hline \multirow{2}{*}{ No } & \multirow{2}{*}{$\begin{array}{l}\text { Nama } \\
\text { Siswa }\end{array}$} & \multicolumn{5}{|c|}{ Skor setiap soal } & \multirow[t]{2}{*}{ Jumlah skor } & \multicolumn{2}{|c|}{$\begin{array}{l}\text { Ketuntasan } \\
\text { belajar }\end{array}$} \\
\hline & & 10 & 20 & 20 & 25 & 25 & & Ya & Tidak \\
\hline 1 & JW & 10 & 20 & 20 & 25 & 25 & 100 & $\sqrt{ }$ & \\
\hline 2 & $\mathrm{HL}$ & 10 & 20 & 20 & 25 & 25 & 100 & $\sqrt{ }$ & \\
\hline 3 & $\mathrm{KM}$ & 10 & 10 & 20 & 20 & 20 & 80 & $\sqrt{ }$ & \\
\hline 4 & NS & 10 & 20 & - & 25 & 25 & 80 & $\sqrt{ }$ & \\
\hline 5 & CR & 10 & 20 & 20 & 25 & 25 & 100 & $\sqrt{ }$ & \\
\hline 6 & WH & 10 & 10 & 20 & 25 & 25 & 90 & $\sqrt{ }$ & \\
\hline 7 & VL & 10 & 20 & 20 & 25 & 25 & 100 & $\sqrt{ }$ & \\
\hline 8 & JA & 10 & 20 & 20 & 25 & 25 & 100 & $\sqrt{ }$ & \\
\hline 9 & JT & 10 & 15 & 20 & 25 & 25 & 95 & $\sqrt{ }$ & \\
\hline 10 & $\mathrm{AL}$ & 10 & 20 & 10 & 25 & 25 & 90 & $\sqrt{ }$ & \\
\hline 11 & GD & 10 & 20 & 20 & 25 & 25 & 100 & $\sqrt{ }$ & \\
\hline 12 & JK & 10 & 20 & - & 25 & 25 & 80 & $\sqrt{ }$ & \\
\hline 13 & $\mathrm{AM}$ & 10 & 20 & 10 & 20 & 20 & 80 & $\sqrt{ }$ & \\
\hline 14 & DT & 10 & 20 & 20 & 25 & 25 & 100 & $\sqrt{ }$ & \\
\hline 15 & BW & 10 & 10 & 20 & 25 & 25 & 90 & $\sqrt{ }$ & \\
\hline 16 & JP & 10 & 20 & 20 & 25 & 25 & 100 & $\sqrt{ }$ & \\
\hline 17 & AR & 10 & 20 & 20 & 25 & 25 & 100 & $\sqrt{ }$ & \\
\hline 18 & VM & 10 & 20 & 10 & 25 & 25 & 90 & $\sqrt{ }$ & \\
\hline 19 & MS & 10 & 20 & 20 & 20 & 20 & 90 & $\sqrt{ }$ & \\
\hline 20 & JM & 10 & - & 20 & 25 & 25 & 80 & $\sqrt{ }$ & \\
\hline 21 & ES & 10 & 20 & 20 & 25 & 25 & 100 & $\sqrt{ }$ & \\
\hline 22 & CS & 10 & 20 & - & 25 & 25 & 80 & $\sqrt{ }$ & \\
\hline \multicolumn{2}{|c|}{$\begin{array}{c}\text { Jumlah } \\
\text { keseluruhan }\end{array}$} & 195 & 220 & 385 & 340 & 535 & 535 & 2.015 & \\
\hline
\end{tabular}

$$
\mathrm{KB}=\frac{2.015}{2.200} \times 100 \%=91,59 \%
$$

Dari data diatas menunjukan bahwa keberhasilan pada skilus II ini sudah mencapai ketuntasan klasikal yaitu $85 \%$, sebab ketuntasan belajar pada siklus II ini mencapai 91, $59 \%$. Hal ini berarti bahwa tindakan yang dilakukan pada siklus II ini berhasil dan tidak perlu dilanjutkan pada siklus berikut.

\section{Pembahasan}

Pada bagian ini dibahas hasil penelitian pembelajaran IPS dengan menggunakan model picture and picture di kelas V SD Katolik Kakaskasen. Adapun pembahasan hasil penelitian berdasarkan temuan penelitian tindakan pada siklus I dan siklus II. Penelitian model picture and picture dilaksanakan dalam dua siklus dan mengikuti alur penelitian tindakan kelas yaitu perencanaan, pelaksanaan, observasi dan refleksi.

a. Pembahasan siklus I

Pelaksanaan tindakan siklus I dimulai dengan menyusun pelaksanaan pembelajaran (RPP) dan instrument penilaian. Dimana dalam perencanaan ini guru menggunakan model picture and picture dalam kegiatan pembelajaran IPS. Dalam pelaksanaan tindakan siklus I ini, peneliti terlebih dahulu mempersiapkan materi sesuai dengan kurikulum, kemudian melaksanakan apersepsi. Sesudah apersepsi guru menjelaskan secara singkat tentang materi yang akan dipelajari. Setelah penjelasan singkat mengenai materi selesai disampaikan guru membagi kelompok, kemudian menyampaikan dan menjelaskan dari masing-masing kelompok dengan memberikan LKS pada tiap kelompok sebagai panduan untuk melaksanakan picture and picture mengenai jenis- 
jenis kegiatan Ekonomi. Ini dilakukan agar siswa dapat bekerja sama dan saling membantu. Setelah pembelajaran selesai peneliti memberikan evaluasi untuk mengukur sejauh mana pemahaman siswa dalam pembelajaran yang menggunakan model picture and picture. Pada pelaksanaan evaluasi dalam proses pengerjaannya dilakukan secara perorangan.

Setelah selesai melaksanakan evaluasi, hasil dari tiap siswa diperiksa untuk melihat hasil belajar siswa pada pembelajaran IPS tentang jenis-jenis kegiatan Ekonomi. Ternyata hasil belajar siswa kurang memuaskan atau tidak sesuai dengan yang diharapkan karena belum mencukupi kriteria keberhasilan pembelajaran yaitu $80 \%$ dengan data yang diperoleh dari 22 orang siswa. Dengan perolehan seperti dibawah ini:

$$
\mathrm{KB}=\frac{1.350}{2.200} \times 100 \%=61,36 \%
$$

Pada kegiatan akhir pembelajaran, peneliti memberikan soal yang berhubungan dengan materi yang sudah diajarkan. Setelah peneliti merefleksi kembali akan berjalannya proses pembelajaran, maka peneliti menemukan penyebab rendahnya hasil belajar siswa. Ternyata disebabkan masih kurang motivasi dari guru dalam menjadikan suasana belajar yang menyenangkan, siswa masih banyak yang bermain dalam mengikuti kegiatan pembelajaran, sehingga datang pada evaluasi mereka tidak mempunyai pegangan dalam menjawab soal yang diberikan.

Bertitik tolak dari kekurangan yang terjadi pada siklus I, maka penelitian dilanjutkan pada siklus berikutnya dengan tetap melihat akan kekurangan dan memenuhi pencapaian kriteria keberhasilan siswa $85 \%$. Dengan terpenuhinya kriteria hasil belajar siswa, maka peneliti berkesimpulan bahwa penelitian tindakan kelas ini diakhiri pada siklus II dan tidak di lanjutkan lagi ke siklus berikut karena dapat dinyatakan berhasil.

\section{b. Pembahasan Siklus II}

Pelaksanaan tindakan kelas pada siklus II ini mengacu pada hasil pelaksanaan siklus I dengan mempersiapkan rencana pelaksanaan pembelajaran dan mengadakan perbaikan tindakan untuk meningkatkan hasil belajar siswa yang belum tercapai pada siklus I. Tindakan yang dilaksanakan pada siklus II ini, materi yang diajarkan pada siklus II ini sama dengan materi yang diajarkan pada siklus I, dengan model picture and picture pada mata pelajaran IPS kelas V SD Katolik Kakaskasen.

Pada siklus yang ke II ini hasil yang dicapai setelah mengadakan perbaikan tindakan pembelajaran yang diterapkan ternyata mengalami peningkatan yang cukup baik dan mencapai target yang diharapkan karena keberhasilan siswa mencapai $85 \%$ dan tindakan dihentikan pada siklus yang ke II ini, karena dinyatakan berhasil. Hasil pembelajaran yang dicapai pada siklus II ini seperti di bawah ini:

$$
\mathrm{KB}=\frac{2.015}{2.200} \times 100 \%=91,59 \%
$$

\section{SIMPULAN DAN SARAN}

Dari hasil penelitian dan pembahasan yang ada, maka peneliti menarik kesimpulan bahwa: 1) Penerapan model picture and picture dapat meningkatkan hasil belajar IPS siswa kelas V SD Katolik Kakaskasen; 2) Model picture and picture membuat siswa aktif dalam proses pembelajaran

Berdasarkan kesimpulan di atas, peneliti mengemukakan saran sebagai berikut: 1) Model picture and picture diharapkan diterapkan oleh guru-guru pada pembelajaran IPS karena dapat meningkatkan hasil belajar siswa; 2) Diharapkan siswa lebih aktif dalam pembelajaran di kelas.

\section{DAFTAR RUJUKAN}

[1] Aqib Zainal. 2006. Penelitian Tindakan Kelas Bandung : CV Yrma Widya.

[2] Aqib, Z. 2013. Model-Model, Media, dan Strategi Pembelajaran Kontekstual (Inovatif). Bandung: Yrama Widya.

[3] Asyafah Abas. 2019. Menimbang Model Pembelajaran (Kajian Teoritis-Kritis Atas Model Pembelajaran dalam Pendidikan Islam). TARBAWY: Indonesian Journal of Islamic Education - Vol. 6 No. 1

[4] Gunawan Rudi. 2011. Pendidikan IPS. Filosofi. Konsep. Dan Aplikasi. Bandung.

[5] Huda, Miftahul. 2014. Cooperative Learning. Yogyakarta: Pustaka Pelajar.

[6] Johnson and Jhonson. 2009. Model Picture and Picture (Http://www.ras-eko.com/2011/05) Diakses tanggal 3 November 2015 
[7] Oemar Hamalik. 1994. Kurikulum dan Plembelajaran. Bandung PT Bumi Aksara.

[8] Sagala Saiful. 2007. Konsep dan Makna Pembelajaran. Bandung: Alphabet.

[9] Sardiyo, dkk 2007. Pendidikan IPS di SD. Jakarta Universitas Terbuka

[10] Tim Pustaka Yustisia. 2008. Panduan Lengkap KTSP SD/MI. SMP dan SMA/SMK Jakarta: Pustaka Yustisia.

[11] Trianto. 2011. Mendesain model pembelajaran inovatif-progresif. Jakarta: Kencana 